\begin{tabular}{|l|l|l||}
\hline \multicolumn{2}{|c|}{ PublisherInfo } \\
\hline \hline PublisherName & $:$ & Palgrave Macmillan UK \\
\hline \hline PublisherLocation & $:$ & London \\
\hline \hline PublisherImprintName & $:$ & Palgrave Macmillan \\
\hline \hline
\end{tabular}

\title{
Publishing productivity measures in ONS
}

\begin{tabular}{|l|l|l||}
\hline \multicolumn{2}{|l|}{ ArticleInfo } \\
\hline \hline ArticleDOI & $:$ & $10.1057 /$ palgrave.elmr.1410103 \\
\hline \hline ArticleCategory & $:$ & Feature \\
\hline \hline ArticleFirstPage & $:$ & 19 \\
\hline \hline ArticleLastPage & $:$ & 21 \\
\hline \hline & & RegistrationDate $: 2007-7-20$ \\
ArticleHistory & $:$ & OnlineDate $\quad$ 2007-7-20 \\
\hline \hline ArticleCopyright & $:$ & Crown copyright2007 \\
\hline \hline
\end{tabular}




\section{Comments on the joint publication launch of this edition of ELMR and The ONS Productivity Handbook.}

This July 2007 Economic \& Labour Market Review (ELMR) is a special productivity edition and is published alongside The ONS Productivity Handbook: A Statistical Overview and Guide. Presenting all Officefor National Statistics (ONS) productivity estimates, sources, methods and analysis, this single volume will serve as a valuable reference on the subject. Articles printed in this edition of ELMR have been chosento complement the new handbook and provide new results from within ONS alongside views from outside the office. This article comments on the jointpublication launch and what readers can gain from it.

Misc

The Full Text of this article can be found on the National Statistics website (http://www.statistics.gov.uk/elmr/07_07/downloads/ELMR_July07_Camus.pdf). 